\title{
Recent Advances in the Study of Marine Microbial Biofilm: From the Involvement of Quorum Sensing in Its Production up to Biotechnological Application of the Polysaccharide Fractions
}

\author{
Paola Di Donato ${ }^{1,2}$, Annarita Poli ${ }^{1}$, Valentina Taurisano ${ }^{1,2}$, Gennaro Roberto Abbamondi ${ }^{1}$, \\ Barbara Nicolaus ${ }^{1, *}$ and Giuseppina Tommonaro ${ }^{1}$ \\ 1 Institute of Biomolecular Chemistry ICB-CNR, Consiglio Nazionale delle Ricerche, Via Campi Flegrei 34, \\ Pozzuoli, Napoli 80078, Italy; paola.didonato@icb.cnr.it (P.D.D.); apoli@icb.cnr.it (A.P.); \\ valentina.taurisano@uniparthenope.it (V.T.); gennaroroberto.abbamondi@icb.cnr.it (G.R.A.); \\ gtommonaro@icb.cnr.it (G.T.) \\ 2 Department of Environmental Sciences, University of Naples "Parthenope", Centro Direzionale, Isola C4, \\ Naples 80143, Italy \\ * Correspondence: bnicolaus@icb.cnr.it; Tel.:+39-0818675245
}

Academic Editor: Magnus Wahlberg

Received: 15 January 2016; Accepted: 25 April 2016; Published: 13 May 2016

\begin{abstract}
The present review will explore the most relevant findings on marine microbial biofilm, with particular attention towards its polysaccharide fraction, namely exopolysaccharide (EPS). EPSs of microbial origin are ubiquitous in nature, possess unique properties and can be isolated from the bacteria living in a variety of habitats, including fresh water or marine environments, extreme environments or different soil ecosystems. These biopolymers have many application in the field of biotechnology. Several studies showed that the biofilm formation is closely related to quorum sensing (QS) systems, which is a mechanism relying on the production of small molecules defined as "autoinducers" that bacteria release in the surrounding environment where they accumulate. In this review, the involvement of microbial chemical communication, by QS mechanism, in the formation of marine biofilm will also be discussed.
\end{abstract}

Keywords: biofilm; marine bacteria; exopolysaccharide (EPS); acylhomoserine lactones (AHLs); quorum sensing (QS)

\section{Introduction}

The ocean covers almost two-thirds of the planet's surface, and with its 3500 million years of life, it represents a mottled source of chemical and biological biodiversity [1]. Effectively, due to the physical and chemical differences, such as temperature, whose range goes from the extreme low values of Antarctic waters to $350^{\circ} \mathrm{C}$ of hydrothermal vents, and pressure (1-1000 atm), the sea can be considered a melting pot of (micro)organisms with intriguing properties related to the production of active secondary metabolites [2].

In particular, these natural products have been widely investigated by the pharmaceutical industry to find new drugs with antiviral, antibacterial and antitumor activities [3-8].

Generally, in the aquatic environment, the production of secondary metabolites by sessile eukaryotic organisms (i.e., marine sponges and corals) can be considered as a defense system against predators that are responsible for the natural selection in biological communities [9].

One of the strategies that bacteria evolved to adapt to environmental challenges is the formation of multicellular aggregates, commonly referred to as biofilms [10]. These bacterial consortia are embedded in an extracellular matrix with protective and adhesive proprieties [11]. 
The scientific interest in this subject is considerable, since bacteria are organized in biofilms in most natural environments [12-14].

At the base of the formation of these aggregates, there is the synthesis by the microorganisms of an extracellular matrix that gives structural integrity to the biofilm [15]. This matrix is made of exopolymers, extracellular polymeric substances, consisting of polysaccharides, proteins, nucleic acids and lipids $[16,17]$. In general, the amount of extracellular polymeric substances in a biofilm varies from $50 \%-90 \%$ of the organic fraction. The extracellular matrix has different basic functions, such as adhesion to surfaces, aggregation of the cells, formation of biofilms and flocs (structural elements), protective barrier for cells, etc.

The biofilm mode of life gives to its members several benefits, including increased resistance to host immune defenses, higher resistance towards antimicrobial compounds, etc. [18]. Moreover, biofilms are most often found in close association with surfaces and interfaces, where they take advantage of a higher concentration of nutrients [19].

Carbohydrates are the major constituents of this matrix. More precisely, the bacterial extracellular polymeric matrix is constituted of polysaccharides $(40 \%-95 \%)$, proteins $(1 \%-60 \%)$, nucleic acids $(1 \%-10 \%)$ and lipids $(1 \%-40 \%)$ [20].

Among these biopolymers, exopolysaccharides represent the major fraction of the biofilm matrix. These high molecular weight polymers are made up of repeating units of pentoses, hexoses and amino sugars assembled by different linkages in an ample variety ranging from stiff backbones to more flexible structures [21]. In addition, inorganic residues, such as phosphate or rarely sulfate, may also be present [22].

The physiological role of exopolysaccharides is influenced by the wide biodiversity of the sea, and it has been extensively demonstrated that they promote both the growth and the survival of the cell aggregates in which they are produced [23-25].

Recently, exopolysaccharides isolated from different bacterial species living in several environments have been characterized. These studies established that the chemical composition of these natural polymers can change even in the frame of a single species. In particular, it resulted that various strains of Streptococcus thermophilus produce heteropolymers with a different monomeric composition, molar ratio and molecular mass [26].

In addition, Pseudomonas aeruginosa was found to produce at least three distinct exopolysaccharides: alginate, a mannose- and galactose-rich polysaccharide named Pel (from pel, the pellicle formation locus) and a glucose-rich matrix polysaccharide polymer (unknown structure) named Psl (from $p s l$, the polysaccharide synthesis locus), which are at the base of biofilm development and architecture [27].

Furthermore, in the case of marine exopolysaccharides, it was extensively demonstrated that the chemical nature of the polymer was influenced by the environment where the microorganisms live.

In particular, exopolysaccharides produced from an Antarctic marine bacteria isolated from both the particulate material and sea ice of the Southern Ocean were shown to be mainly composed of charged uronic acids moieties and sulfate groups [23]. On the other hand, the exopolymer produced by the haloalkalophilic Bacillus sp. I-450, isolated in the Korean Yellow Sea, was found to be an acidic polysaccharide with a high content of neutral sugars and uronic acids [28].

Hetero- and homo-polymers of mannose were instead identified in the case of microorganisms isolated from marine hot springs and hydrothermal vents [10].

Since the discovery of bacterial aggregates enclosed in biofilms, many studies have been carried out in order to establish the regulatory mechanism at the base of these "social lives" [29].

Actually, when organized in communities, microbial cells collaborate by means of a cell-cell signaling system, defined as quorum sensing (QS), based on the production of small molecules or "autoinducers", whose release is proportional to the density and the size of the (micro-)systems where they accumulate [30]. 
In particular, it has been extensively demonstrated that this communication system is at the base of the interaction among pathogens [31,32], but many clues have been collected related to the use of the same mechanism by marine bacteria.

In fact, studies carried out on Vibrio spp. (Vibrio fischeri, Vibrio anguillarum and Vibrio harveyi) highlighted the involvement of the QS system in the control of the bio-luminescence, virulence processes and biofilm production [33-35]. Moreover, it has been discovered that bacteria isolated from extreme marine environments, living alone or in association with planktonic species, are able to produce "inducers" of the homoserine lactones system (AHLs) involved in EPS production [36]. As reported by Frederick et al., 2011, the production of extracellular polymeric substances regulated by QS allows the formation of biofilms able to evolve rapidly from an initial colonization stage to a later stage in which a large amount of exopolysaccharides is produced as a defense against environmental threats [37].

Here, a brief overview on marine microbial biofilm with particular attention towards biotechnological application of the polysaccharide fraction will be handled. Furthermore, a brief discussion on the involvement of quorum sensing in the biofilm production will be provided.

\section{Marine Microbial Exopolysaccharides: Isolation and Purification Strategies}

Marine EPSs are produced by a variety of microbial species that include bacteria, cyanobacteria and Actinobacteria. Depending on the source microorganisms and their growth conditions, two general schemes for EPS isolation and purification can be outlined as shown in Figure 1. When liquid bacterial culture is exploited, then the first step of isolation will require centrifugation to remove intact cells. The cell-free supernatant will be added by cold ethanol (acetone or methanol can be used as alternative solvents), then the EPS is recovered by centrifugation and purified by dialysis (Figure 1, upper part). On the other hand, when bacteria are grown in static mode, for example by seeding on agar plates, the isolation procedure will require a previous step of saline solution washing, to recover the biofilm, followed by the addition of bacteriostatic agents and centrifugation to remove intact cells. The EPS then can be precipitated by the addition of isopropyl alcohol and then purified by dialysis (Figure 1, lower part).

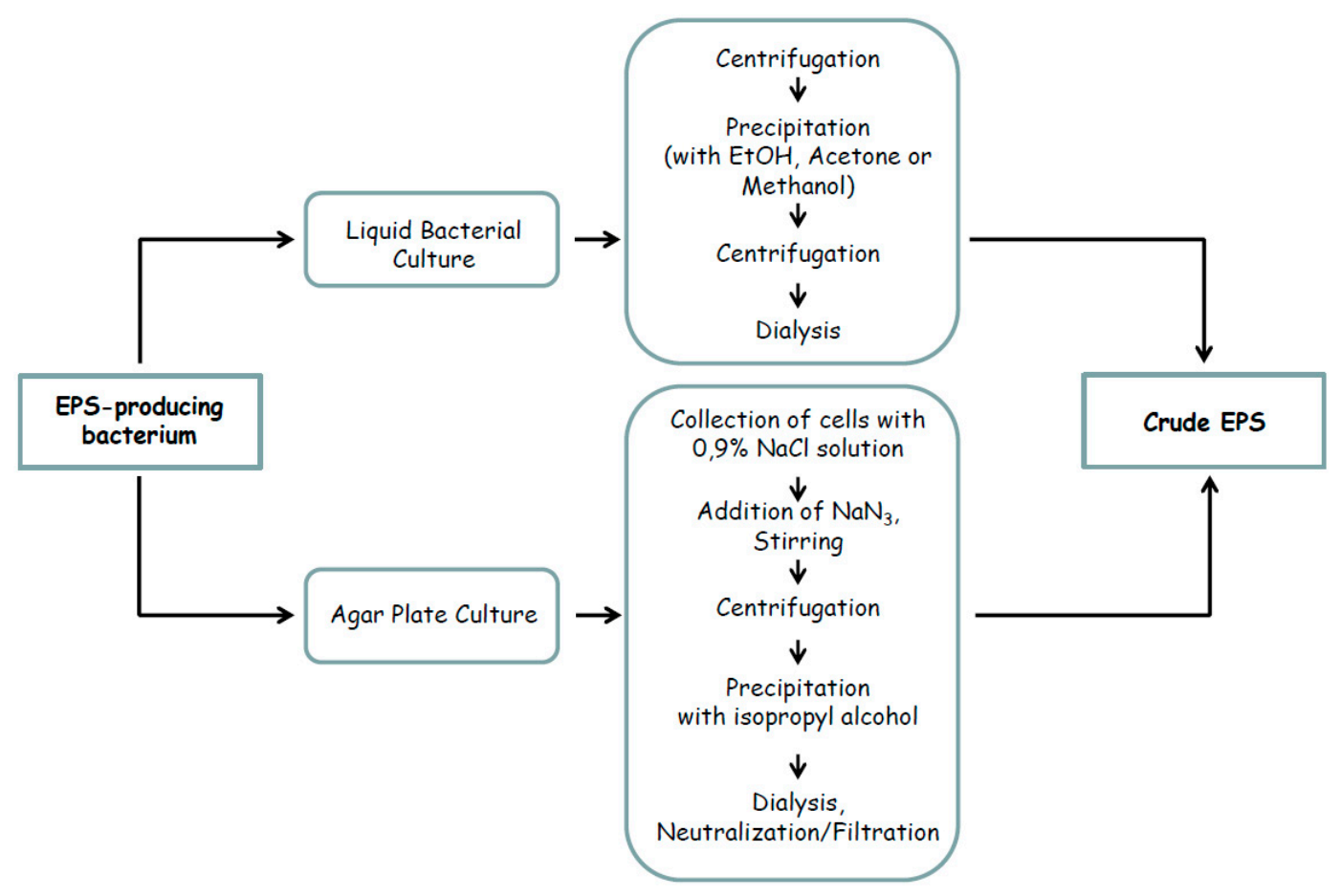

Figure 1. General scheme for EPS isolation [38]. 
Other purification strategies that proved to be very effective are represented by stirred-cell ultrafiltration and crossflow ultrafiltration. As reported in the case of diatom's EPS purification, both techniques were more effective than ethanol precipitation, also affording higher purity of the sample. On the other hand, they were shown to be more time consuming besides affording different EPS chemical compositions depending on the treatment used [39]. Purification by means of ultrafiltration in stirred cells has been applied also to microbial EPS recovery, as for example in the case of Lactobacillus rhamnosus for which the exopolysaccharide recovery ranged from about $80 \%$ up to more than $100 \%$ when compared to the classical alcohol precipitation followed by filtration and freeze drying [40].

\section{Marine Microbial Exopolysaccharides: Biotechnological Applications}

EPSs find applications or could be potentially exploited in several industrial sectors, like for example, in the pharmaceutical field, for tissue engineering or as new anticancer drugs or additives, in the cosmetic industry, in the food industry, as additives or prebiotics, in environmental protection as emulsifiers for oil pollution recovery or as chelators for toxic metals removal, etc.

Several interesting examples of biologically- and biotechnologically-useful EPSs are available in the literature and have been recently reviewed [41]; here, we also report some remarkable and more recent examples as listed in Table 1.

Marine bacterial EPSs that have been investigated for their potential applications in regenerative medicine include the EPSs from Vibrio diabolicus and Alteromonas infernus, two marine bacteria isolated from a deep-sea hydrothermal vent. The EPS from $V$. diabolicus, strain $\mathrm{HE} 800^{\mathrm{T}}$, is a linear hyaluronic acid-like and high molecular weight polymer $\left(8 \times 10^{5} \mathrm{Da}\right)$ (see Table 1 for the chemical composition) commercialized with the name Hyalurift ${ }^{\circledR}$. It has been investigated for its regenerating activity on bone and skin: interestingly, HE800 EPS resembles the glycosaminoglycan hyaluronan and has been shown to be able to promote in vivo regeneration of bone, besides stimulating collagen structuring and extracellular matrix settling in dermal fibroblasts. The EPS from A. infernus, strain GY785, has a high molecular weight (about $10^{6} \mathrm{Da}$ ) and is a branched and low sulfated polysaccharide (see Table 1 for the chemical composition) [42,43]. GY785 EPS was shown to improve the mechanical properties of cellulose-based hydrogels used for cartilage tissue engineering applications.

Furthermore, the depolymerization products of these two EPSs also showed useful properties. HE800 DR, the low molecular weight derivative of HE800 EPS, was shown to be potentially active against tumor cells by acting on the complement system. Similar properties were displayed also by the depolymerization product of GY785 EPS, named GY785 DR. The main chemical features of HE800 and GY785 EPSs are reported in Table 1 [44]. Moreover, GY785 EPS after depolymerization $\left(24 \times 10^{3} \mathrm{Da}\right)$ and sulfation treatments displays also an interesting "heparin-like" or "heparin-mimetic" activity (Table 1).

Another species belonging to Alteromonas genus, i.e., Alteromonas macleodii subsp. fijiensis, strain HYD657, has been shown to produce interesting EPS. A. macleodii subsp. fijiensis bacterium produces a high molecular weight $\left(1.5 \times 10^{6} \mathrm{Da}\right)$ polymer, i.e., HYD657, that is commercially available with the name Abyssine ${ }^{\circledR}$ (Patent PCT 94907582-4) for the protection of sensitive skin against chemical, mechanical and UVB aggressions [45]. Its main chemical features are shown in Table 1. Notably, this is the first example of marine EPS to be commercially exploited by the cosmetic industry.

Other EPSs displaying potential pharmaceutical applications are secreted by polar microorganisms, like the strain SM1127, belonging to the Polaribacter genus, that has been isolated from the brown alga Laminaria in the Arctic environment. This EPS (molecular weight $220 \mathrm{kDa}$ ) is mainly composed of $N$-acetyl glucosamine, mannose and glucuronic acid (see Table 1 for the complete monomer composition). It is safe for oral administration and external use, and it is able to exert a protective effect towards human dermal fibroblasts. EPS from Polaribacter sp. SM1127 could also find applications in food, cosmetic and biomedical fields, thanks to its rheological properties, its high tolerance to salinity $\mathrm{pH}$ and, finally, its moisture-retention ability [46]. 
A similarly versatile EPS has been identified from the deep-sea bacterium Zunongwangia profunda SM-A87: such a molecule possesses interesting rheological properties, very high moisture-retention ability and antioxidant activity, which make it a promising candidate for biotechnology applications [47].

A very recent example of biologically-active EPS is represented by the sulfated polysaccharide produced by Labrenzia sp. PRIM-30, a bacterium isolated from deep seawater collected in the region of Cochin in India. This EPS has an average molecular weight of $269 \mathrm{kDa}$; its monomer units include glucose, arabinose, galacturonic acid and mannose in the ratio of 14.4:1.2:1:0.6. Its low viscosity, emulsifying activities, besides its antioxidant properties suggest its applications in the food and pharmaceutical fields [48].

The EPS produced by the marine bacterium Cobetia marina, isolated from littoral seawater in Woodshole (USA), has been recently studied for its structure and biological properties. This EPS is an acidic and high molecular weight heteropolysaccharide $(270 \mathrm{kDa})$, whose repeating unit is the following: of $\rightarrow 2)-\beta$-D-Rib $f$ - $(1 \rightarrow 4)$-[7,8-O-(Pyr)]- $\alpha$-D-KDO $p$ - $(2 \rightarrow$. Interestingly, the EPS composition and structure share significant analogies with some Escherichia coli $\mathrm{K}$-antigen polysaccharides, and therefore, it could be evaluated for potential medical or biotechnological applications [49].

Recently, EPSs produced by Alteromonas sp. PRIM-21, Nitratireductor sp. PRIM-24 and Enterobacter sp. PRIM-26, i.e., bacteria associated with marine organisms, have been isolated. All of the EPSs produced by these strains showed the presence of biologically-important functional groups that suggest their use for biotechnological applications thanks to their good antioxidant and emulsifying properties [50]. 
Table 1. Examples of biologically- and biotechnologically-useful marine EPSs.

\begin{tabular}{|c|c|c|c|}
\hline Bacterial Source(EPS name) & Structure/Chemical Composition * & Activity/Applications & Ref. \\
\hline Vibrio diabolicus, strain $\mathrm{HE} 800^{\mathrm{T}}$ & $\begin{array}{c}\text { Equal amounts of GlcA and hexosamine (GlcNAc } \\
\text { and GalNAc) }\end{array}$ & Regenerating activity on bone and skin & [42] \\
\hline Alteromonas infernus (GY785) & $\begin{array}{l}\text { Repeating unit of uronic acids (GlcA and GalA) } \\
\text { and neutral sugars (Gal and Glc) and substituted } \\
\text { with one sulfate group }\end{array}$ & $\begin{array}{l}\text { Increase the viability and the proliferation of } \\
\text { chondrocytes. Cartilage tissue engineering } \\
\text { applications. "Heparin-like" or "heparin-mimetic" } \\
\text { activity (depolymerized and sulfated EPS). }\end{array}$ & {$[42,43]$} \\
\hline $\begin{array}{l}\text { Alteromonas macleodii subsp. } \\
\text { Fijiensis, strain HYD657 }\end{array}$ & $\begin{array}{c}\text { Monomer composition: } \\
\text { Glc/Gal/Man/Rha/Fuc/GlcA/GalA } \\
\text { (molar ratios: } 1 / 1.9 / 0.4 / 0.6 / 0.2 / 1.2 / 2.8 \text { ) } \\
\text { Monomer composition: }\end{array}$ & $\begin{array}{l}\text { Protection of sensitive skin against chemical, } \\
\text { mechanical and UVB aggressions }\end{array}$ & {$[45]$} \\
\hline Polaribacter sp. SM1127 & $\begin{array}{c}\text { Rha/Fuc/GlcA/Man/Gal/Glc/GlcNAc (mol\%: } \\
\text { 0.8/7.4/21.4/23.4/17.3/1.6/28.0) }\end{array}$ & Food, cosmetic, pharmaceutical and biomedical fields & [46] \\
\hline $\begin{array}{l}\text { Weissella cibaria A2, Weissella confusa } \\
\text { A9, Lactobacillus plantarum A3 and } \\
\text { Pediococcus pentosaceus } 5 \mathrm{~S} 4\end{array}$ & unknown & $\begin{array}{l}\text { Prebiotic activity (Bifidobacteria group), high } \\
\text { resistance to gastric and intestinal digestion }\end{array}$ & [51] \\
\hline $\begin{array}{l}\text { Paracoccus zeaxanthinifaciens subsp. } \\
\text { payriae (EPS M1) }\end{array}$ & $\begin{array}{l}\text { Proteins, neutral sugars, uronic acids, sulfates } \\
(w / w) 3 \%, 48 \%, 8 \%, 29 \% \text {, respectively. } \\
\text { Substituents: acetate and sulfate }\end{array}$ & Bioremediation of toxic metals & [52] \\
\hline Anabaena spiroides & $\begin{array}{c}w / w \text { composition: Glc } 29.3 \% \text {, Man } 24.2 \% \text {, } \\
\text { Rha } 21.9 \% \text {, Xyl 7.8\%, GlcA 6.6\%, Fuc } 5.6 \% \text {, } \\
\text { Gal } 2.0 \% \text {, GalA } 1.8 \% \text { and Ara } 0.8 \% \text {; proteins } 12.2 \%\end{array}$ & $\begin{array}{l}\text { Bioremediation of metal-polluted environments } \\
\text { (copper), reduction of copper accumulation in an } \\
\text { aquatic microbial food chain }\end{array}$ & [53] \\
\hline Pseudomonas aeruginosa JP-11 & unknown & $\begin{array}{l}\text { Bioremediation of polluted waters by binding of toxic } \\
\text { cadmium ions }\end{array}$ & [54] \\
\hline Pseudomonas sp. ID1 & $\begin{array}{c}w / w \text { composition: carbohydrates } 33.8 \% \\
(\text { Glc } 17.0 \%, \text { Gal } 8.6 \% \text {, Fuc } 8.2 \%) / \text { uronic acids } \\
2.4 \% / \text { proteins } 2.8 \%\end{array}$ & $\begin{array}{l}\text { Emulsifying and cryoprotectant properties. } \\
\text { Potential applications in bioremediation and in food, } \\
\text { pharmaceutical and cosmetic sectors. }\end{array}$ & [55] \\
\hline
\end{tabular}


EPSs produced by lactic acid bacteria isolated from the gastrointestinal tract of fish (Dascyllus aruanus) display promising prebiotic activity thanks to their ability to resist gastric and intestinal digestion and to positively affect some beneficial gut bacteria, particularly with the main regard to Bifidobacteria [51].

Marine microbial EPSs can be involved in bioremediation processes to remove toxic metals. An example is represented by the sulfated EPSs (see Table 1 for the main chemical features) produced by Paracoccus zeaxanthinifaciens subsp. payriae, a species isolated from microbial mats in the Rangiroa Atoll (French Polynesia). Interestingly, such a biopolymer displayed a high biosorption capacity, since it is able to perform a significant $\mathrm{Cu}$ (II) and $\mathrm{Ag}$ (I) uptake, up to $400 \mathrm{mg} \mathrm{Cu} / \mathrm{g}$ EPS and $256 \mathrm{mg} \mathrm{Ag} / \mathrm{g}$ EPS [52].

Furthermore, cyanobacteria EPSs have been shown to interact with metal ions in metal-polluted environments, thus assuming a potential ecological role for bioremediation. A recent study on the effects of Anabaena spiroides EPS on copper speciation showed that this EPS is able to accumulate Cu (II) ions, thus reducing the in vitro accumulation in an experimental aquatic microbial food chain [53].

Another interesting example of the application to bioremediation is represented by Pseudomonas aeruginosa JP-11 EPS, which has been used for the synthesis of cadmium sulfide nanoparticles. The incorporation of nanoparticles in P. aeruginosa EPS has been proposed as a potential strategy for the efficient removal of toxic cadmium ions from polluted waters [54].

EPSs can be exploited in bioremediation processes also thanks to their emulsifying and cryoprotectant properties, like for example, the biopolymer produced by Pseudomonas sp. ID1, a cold-adapted bacterium isolated from the South Shetland Islands (Antarctica). This EPS (see Table 1 for the chemical composition) has a high molecular weight $\left(2 \times 10^{6} \mathrm{Da}\right)$ and is able to emulsify oils from food and cosmetic origin; moreover, it displays a significant cryoprotective action for Pseudomonas sp. ID1 and for other bacteria, thus suggesting potential applications in food, pharmaceutical and cosmetic sectors [55].

Other examples of marine bacteria EPSs able to emulsify different kinds of hydrocarbons are represented by the EPSs produced by the bacteria Vibrio furnissii strain VB0S3 and Enterobacter cloaceae. The $V$. furnissii strain VB0S3 produces an EPS mainly composed of glucose and galactose that is able to efficiently emulsify crude oil, xylene, diesel and toluene [56]. E. cloaceae produces a fibrous EPS characterized by a pseudoplastic nature and that is able to emulsify benzene, hexane, kerosene and xylene, besides cotton seed, paraffin, coconut, castor, jojoba, groundnut and sunflower oils [57]. Cryoprotectant properties have been shown by EPS from Pseudoalteromonas strain SM20310: this high molecular weight polysaccharide (more than $2 \times 10^{6} \mathrm{Da}$ ) has a 2- $\alpha-, 6-\alpha$-mannosyl residue backbone and has been shown to act as a cryoprotectant agent towards either the producing strain or other bacteria, like Escherichia coli [58].

\section{Quorum Sensing and Biofilm Development}

The first paper reporting the correlation between biofilm development and the quorum sensing (QS) mechanism in Pseudomonas aeruginosa was by David et al., 1998 [59]. The mentioned study demonstrated that the cell-cell signaling is crucial for the differentiation of individual cells of P. aeruginosa into complex multicellular structures (biofilm). P. aeruginosa is an opportunistic biofilm producing bacterium widely recognized in individuals with genetic cystic fibrosis (CF). In the biofilm matrix during lung infection, it produces alginate, a capsular polysaccharide virulence factor, which makes it able to resist antibiotics and to establish chronic infections in the CF lung. Alginate is a high molecular weight, acetylated polymer composed of non-repetitive monomers of $\beta$-1,4-linked L-guluronic and D-mannuronic acids. Alginate seems to protect $P$. aeruginosa from the reactive oxygen species produced during the inflammation process, through its free radical scavenging activity. Moreover, it has been reported that $P$. aeruginosa also produced two different polysaccharides, a mannose- and galactose-rich polysaccharide named Pel (from pel, the pellicle formation locus) and a glucose-rich matrix polysaccharide polymer (unknown structure) named Psl (from psl, the 
polysaccharide synthesis locus), which contribute to biofilm formation in nonmucoid strains, which are believed to be the first to colonize CF lung [27].

The QS mechanism is based on the production of signal molecules, mainly the acylhomoserine lactones (AHLs) (Figure 2) in Gram-negative bacteria, the autoinducer 2 (AI2), both in Gram-negative and Gram-positive bacteria, and modified peptides in several Gram-positive bacteria [60-63].

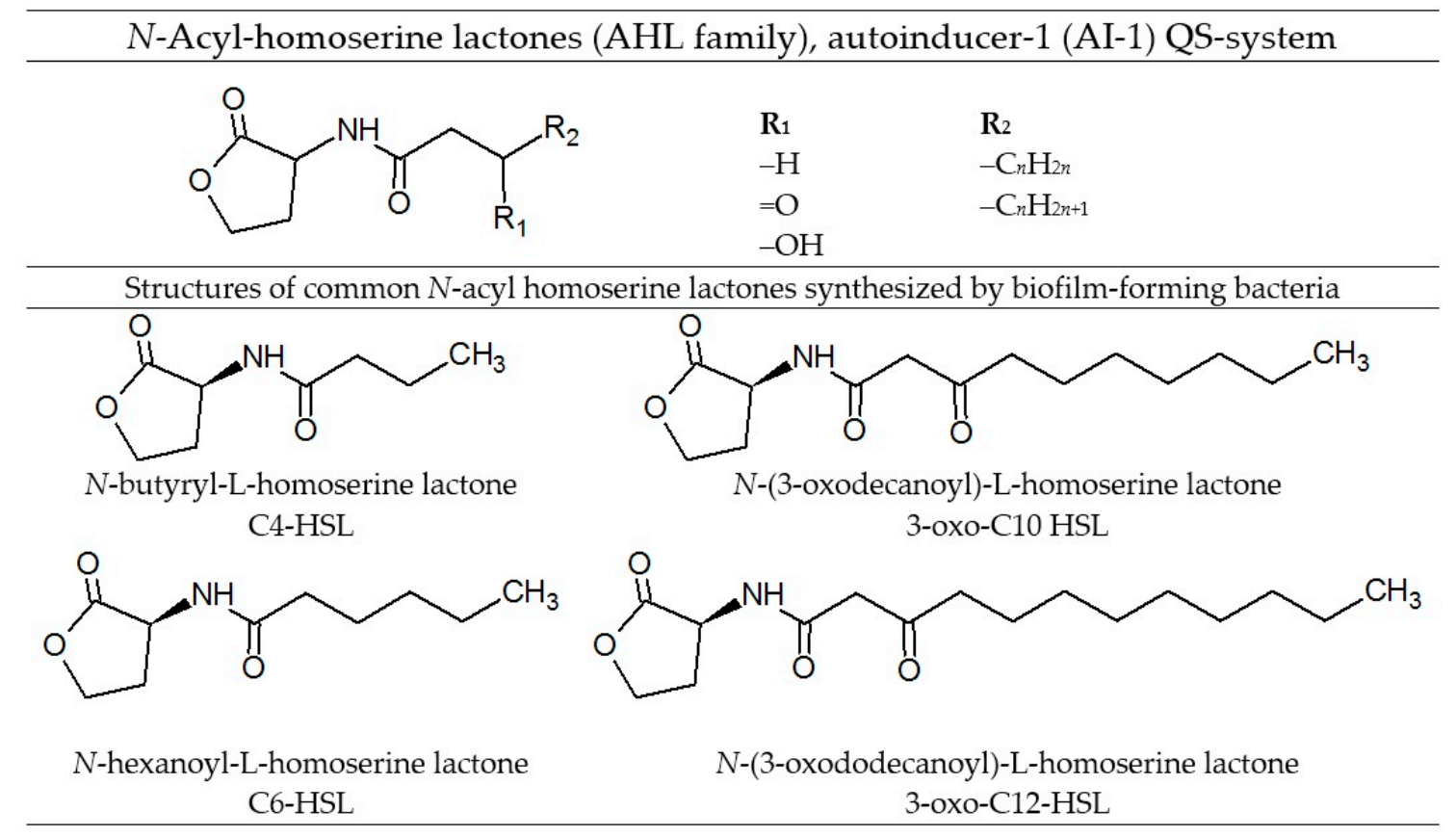

Figure 2. Chemical structures of $N$-acyl homoserine lactones identified in the QS system of biofilm-forming bacteria.

Much information is available in the literature about the production of QS signals by terrestrial bacteria and pathogens, but less about marine bacteria $[64,65]$. The first example reported in the literature of marine bacteria producing QS signals was Vibrio fischeri, which colonizes the light organ of squid Euprymna scolopes. When the bacterial population reaches the "quorum" value, a visible light is produced by the bacteria and regulated by AHLs [66]. Bacteria associated with marine sponges also produce QS signal molecules, mainly AHLs and also diketopiperazines [63].

In $P$. aeruginosa, the QS system is mediated by the two $N$-acylhomoserine lactone autoinducers $\mathrm{N}$-butyryl-L-homoserine lactone (C4-HSL) and $\mathrm{N}$-(3-oxododecanoyl)-L-homoserine lactone (3-oxo-C12-HSL) (Figure 2). This signaling system appears to control genes essential for the formation of differentiated multicellular microcolonies in bacterial biofilms [67]. Indeed, C4-HSL is responsible for the regulation of genes involved in biosurfactant production, while 3-oxo-C12-HSL is crucial for the EPS production and biofilm formation [68,69].

In the marine habitat, many bacteria belonging to the genera Pseudoalteromonas, Thalassomonas, Vibrio and Pseudomonas have been described to produce AHLs [70]. P. aeruginosa N6P6, isolated from seawater after enrichment with two polycyclic aromatic hydrocarbons (PAHs), is a biofilm-forming and acylhomoserine lactone producing bacterium. This marine bacteria putatively synthesized 3-oxo-C12-HSL and C4-HSL, and the two QS genes coding for AHL synthase, lasI and rhlI, were identified. The expression of the two genes during the biofilm mode of growth was different. Indeed, the expression of rhlI decreased during the log phase of biofilm growth, while the expression of lasI increased with the increase in biofilm growth. This difference in the lasI and rhlI genes' expression significantly affected the biofilm architecture and PAH degradation rate, as well [71].

Aeromonas hydrophila, an opportunistic pathogen of fish and man, forms biofilms and produces C4-HSL and N-hexanoyl-homoserine lactone (C6-HSL) (Figure 2) in a ratio of about 70:1. The capacity 
of A. hydrophila to produce biofilm was compared to a mutant (ahyl) that has lost the capacity to produce C4-HSL and therefore did not form biofilm. This defect was partially restored by the addition of exogenous C4-HSL. This result supports a crucial role of AHL signal molecules in A. hydrophila biofilm development [72].

A very interesting paper reported that the extract of Trigonella foenum-graecum seed methanol extract was able to inhibit AHL-regulated virulence factors, such as biofilm forming ability and EPS production, of both above-mentioned bacteria, P. aeruginosa and A. hydrophila. Indeed, the total amount of EPS produced and biofilm formation were inhibited in a concentration-dependent manner by T. foenum-graecum extract. Further study demonstrated that the major compound present in the extract and identified by GC-MS was caffeine, which really reduced the production of QS-regulated virulence factors and biofilm at $200 \mu \mathrm{g} / \mathrm{mL}$. These results confirmed the previews data reported by Norizan et al., 2013 [73,74].

A large class of marine bacteria is represented by the genus Vibrio, the most studied marine microorganisms for their QS properties. The discovery of luminescence in the marine bacteria $V$. fischeri in the late 1970s proved the existence of a system regulating the cell-cell communication by means of signal molecules [69,75].

Vibrio sp. strain T33, isolated from a Malaysian tropical marine water sample, was identified by using $16 \mathrm{~S}$ rDNA gene sequence analysis, and it was closely related to Vibrio brasiliensis. It was proven to produce C6-HSL and N-(3-oxodecanoyl)-L-homoserine (3-oxo-C10 HSL) (Figure 2) and has been shown to form biofilm. Moreover, catechin, a well-known anti-QS compound [76], significantly inhibited the biofilm formation by Vibrio sp. strain T33. These results suggested that the formation of biofilm formation in Vibrio sp. strain T33 is regulated by QS [77]. Later, the same authors reported similar data for another marine bacteria belonging to the same genus Vibrio sp., V. sinaloensis strain T47. The isolated strain was confirmed to produce C4-HSL, and it also formed biofilms, which were inhibited by catechin [78].

The marine bacterium Pseudoalteromonas ulvae TC14 isolated from the Mediterranean Sea [79] is reported as producer of a purple pigment, identified and characterized as violacein. The production of the pigment was higher in the medium in which it grew less, and it was regulated from exogenous AHLs. Moreover, other phenotypes associated with biofilm formation, such as adhesion and motility, also were regulated by exogenous AHLs. Results suggested that $P$. ulvae TC14 possessed a functional Lux-type QS receptor capable of detecting extrinsic AHLs, which control violacein production, motility, adhesion and biofilm formation [80].

Marine snow, like the biofilm, represents a strategy of defense that a bacterial community adopts to display antagonistic activities towards other bacteria [81]. This bacterial interaction also occurs at high microbial density; indeed, the levels of microorganisms in marine and lake snow are around $10^{8}-10^{9}$ cells $\mathrm{mL}^{-1}$, which means 100 - to 10,000 -fold higher than those in the surrounding water columns [82-84]. Some members of $\alpha$-Proteobacteria belonging to the genus of Roseobacter isolated from marine and lake snows produced signal molecules (AHLs). In this study, the authors suggested that AHLs produced in Roseobacter species and other marine snow bacteria control phenotypic traits, such as antibiotic and/or hydrolytic enzymes or biofilm formation, which are observed when the population reaches high density and when bacteria attached to snow particles, like in the marine snow community [36].

Even though all reported results confirm the concept that the cell-cell communication system (quorum sensing) is directly involved in the biofilm development in several bacterial species and conditions, biofilm formation is a multifactorial and complex issue. Many items (nutrient load, intracellular carbon flux, hydrodynamics) have a significant impact on biofilm formation, probably by altering cellular features during the different stages of bacterial growth and biofilm development. Therefore, the regulation of QS is important for the biofilm development for many microorganisms in different conditions, but it is not a unique and important factor [85]. 


\section{Conclusions}

Many studies have been addressed towards the understanding of the fundamental features concerning the behavior of cells in a biofilm. With a deep knowledge in the production and development of biofilm, as well as its chemical composition and physicochemical properties, an improved biotechnology with implications for science, industry, bioremediation and human health could be provided. Among all constituents of bacterial biofilm, the polysaccharide component (if present) represents the most interesting fraction for its medical, industrial and environmental applications.

Exopolysaccharides (EPS) of microbial origin, as a reflection of the many functions they perform in the environment and their chemical and structural variety, have many applications in the field of biotechnology, especially in the pharmaceutical, food and petrochemical industries. The prospects regarding the discovery of new polysaccharides, with better characteristics than those already known, seem optimistic thanks also to the diversity offered by the microorganisms. The conditions, especially in terms of temperature, salinity and oxygen, make the sea a privileged field of investigation for the discovery of new bacterial species and, therefore, of biomolecules with novel properties. This review reflects the current state of research in the field of marine bacteria producing biofilm, which seeks to expand the exploitation of nature as a source of new active agents to be used as leads for the development of effective remedies for a multitude of applications. The identification of new natural products with the specific aim of clarifying the chemical bases of the compounds and the feedback dose-effect and structure-activity are always in progress. Some examples of marine biofilm and EPS have been reported according to their function and their biotechnological properties, as well as the role of signal molecules in their production. Although natural substances have been used in medicine for thousands of years, the full therapeutic potential of the natural chemical diversity is still far from being understood, and significantly, in particular, our level of understanding of the role of these secondary metabolites in vital processes is still scarce.

Acknowledgments: This work was partially supported by the project PON03PE_00107_1 BioPoliS "Sviluppo di tecnologie verdi per la produzione di BIOchemicals per la sintesi e l'applicazione industriale di materiali POLImerici a partire da biomasse agricole ottenute da sistemi colturali Sostenibili nella Regione Campania".

Author Contributions: P.D.D. and G.T. conceived and designed the analysis; V.T. and G.R.A. performed the experiments; A.P. and B.N. analyzed the data; P.D.D., G.T., A.P. and B.N. wrote the paper. All authors read and approved the final manuscript.

Conflicts of Interest: The authors declare no conflict of interest.

\section{References}

1. Albericio, F.; Álvarez, M.; Cuevas, C.; Francesch, A.; Pla, D.; Tulla-Puche, J. The Sea as a Source of New Drugs. In Molecular Imaging for Integrated Medical Therapy and Drug Development, 1st ed.; Tamaki, N.M.D., Yuji, K., Eds.; Springer Japan, Springer-Verlag: Tokyo, Japan, 2010; pp. 237-249.

2. Jha, R.K.; Xu, Z. Biomedical Compounds from Marine organisms. Mar. Drugs 2004, 2, 123-146. [CrossRef]

3. Manivasagana, P.; Venkatesana, J.; Sivakumarc, K.; Kima, S.K. Pharmaceutically active secondary metabolites of marine actinobacteria Panchanathan. Microbiol. Res. 2014, 169, 262-278. [CrossRef] [PubMed]

4. Bhatnagar, I.; Kim, S.K. Immense Essence of Excellence: Marine Microbial Bioactive Compounds. Mar. Drugs 2010, 8, 2673-2701. [CrossRef] [PubMed]

5. Carte, B.K. Biomedical potential of marine natural products. Bioscience 1996, 46, 271-286.

6. Erba, E.; Bergamaschi, D.; Ronzoni, S.; Faretta, M.; Taverna, S.; Bonfanti, M.; Catapano, C.V.; Faircloth, G.; Jimeno, J.; D'Incalci, M. Mode of action of thiocoraline, a natural marine compound with anti-tumour activity. Br. J. Canc. 1999, 80, 971-980. [CrossRef] [PubMed]

7. Riedlinger, J.; Reicke, A.; Zähner, H.; Krismer, B.; Bull, A.T.; Maldonado, L.A. Abyssomicins, inhibitors of the para-aminobenzoic acid pathway produced by the marine Verrucosispora strain AB-18-032. J. Antibiot. 2004, 57, 271-279. [CrossRef] [PubMed] 
8. Shin, H.J.; Kim, T.S.; Lee, H.S.; Park, J.Y.; Choi, I.K.; Ho, Y.; Kwon, H.J. Streptopyrrolidine, an angiogenesis inhibitor from a marine-derived Streptomyces sp. KORDI-3973. Phytochemistry 2008, 69, 2363-2366. [CrossRef] [PubMed]

9. Berenbaum, M.R. The chemistry of defense: Theory and practice. P.N.A.S. USA 1995, 92, 2-8. [CrossRef]

10. Poli, A.; Anzelmo, G.; Nicolaus, B. Bacterial Exopolysaccharides from Extreme Marine Habitats: Production, Characterization and Biological Activities. Mar. Drugs 2010, 8, 1779-1802. [CrossRef] [PubMed]

11. Decho, A.W. Microbial exopolymer secretions in ocean environments: Their role(s) in food webs and marine processes. Oceanogr. Mar. Biol. 1990, 28, 73-153.

12. Costerton, J.W.; Lewandowski, Z.; Caldwell, D.E.; Korber, D.R.; Lappin-Scott, H.M. Microbial biofilms. Annu. Rev. Microbiol. 1995, 49, 711-745. [CrossRef] [PubMed]

13. Hall-Stoodley, L.; Costerton, J.W.; Stoddley, P. Bacterial biofilms: From the natural environment to infectious diseases. Nat. Rev. Microb. 2004, 2, 95-108. [CrossRef] [PubMed]

14. Flemming, H.C.; Wingender, J. The biofilm matrix. Nat. Rev. Microbiol. 2010, 8, 623-633. [CrossRef] [PubMed]

15. Branda, S.; Vik, A.; Friedman, L.; Kolter, R. Biofilms: The matrix revisited. Trends Microbiol. 2005, 13, $20-26$. [CrossRef] [PubMed]

16. Burmølle, M.; Ren, D.; Bjarnsholt, T.; Sørensen, S.J. Interactions in multispecies biofilms: Do they actually matter? Trends Microbiol. 2014, 22, 84-91. [CrossRef] [PubMed]

17. Hori, K.; Matsumoto, S. Bacterial adhesion: From mechanism to control. Biochem. Eng. J. 2010, 48, 424-434. [CrossRef]

18. De Rossi, B.P.; Calenda, M.; Vay, C.; Franco, M. Biofilm formation by Stenotrophomonasmaltophilia isolates from device-associated nosocomial infections. Rev. Argent. Microbiol. 2007, 39, 204-212.

19. Palmer, J.; Flint, S.; Brooks, J. Bacterial cell attachment, the beginning of a biofilm. J. Ind. Microbiol. Biotechnol. 2007, 34, 577-588. [CrossRef] [PubMed]

20. Flemming, H.C.; Wingender, J. Relevance of microbial extracellular polymeric substances (EPSs) - Part II: Technical aspects. Water Sci. Technol. 2001, 43, 9-16. [PubMed]

21. Kenne, L.; Lindberg, B. Bacterial polysaccharides. In The Polysaccharides; Aspinall, G.O., Ed.; Academic Press: New York, NY, USA, 1983; Volume 2, pp. 287-363.

22. Sutherland, I.W. The best and most comprehensive overview of the polysaccharide moiety of EPS. In Comprehensive Glycoscience; Kamerling, J.P., Ed.; Elsevier: Doordrecht, The Netherland, 2007; Volume 2, pp. 521-558.

23. Nichols, C.A.; Guezennec, J.; Bowman, J.P. Bacterial Exopolysaccharides from Extreme Marine Environments with Special Consideration of the Southern Ocean, Sea Ice, and Deep-Sea Hydrothermal Vents: A Review. Mar. Biotechnol. 2005, 7, 253-271. [CrossRef] [PubMed]

24. McDougald, D.; Rice, S.A.; Barraud, N.; Steinberg, P.D.; Kjelleberg, S. Should we stay or should we go: Mechanisms and ecological consequences for biofilm dispersal. Nat. Rev. Microb. 2011, 10, 39-50. [CrossRef] [PubMed]

25. Gugliandolo, C.; Spanò, A.; Maugeri, T.L.; Poli, A.; Arena, A.; Nicolaus, B. Role of Bacterial Exopolysaccharides as Agents in Counteracting Immune Disorders Induced by Herpes Virus. Microorganisms 2015, 3, 464-483. [CrossRef]

26. Vaningelgem, F.; Zamfir, M.; Mozzi, F.; Adriany, T.; Vancanneyt, M.; Swings, J.; de Vuyst, L. Biodiversity of exopolysaccharides produced by Streptococcus thermophilus strains is reflected in their production and their molecular and functional characteristics. Appl. Environ. Microb. 2004, 70, 900-912. [CrossRef]

27. Ryder, C.; Byrd, M.; Wozniak, D.J. Role of exopolysaccharides in Pseudomonas aeruginosa biofilm development. Curr. Opin. Microbiol. 2007, 10, 644-648. [CrossRef] [PubMed]

28. Kumar, C.G.; Joo, H.S.; Choi, J.W.; Koo, Y.M.; Chang, C.S. Purification and characterization of an extracellular polysaccharide from haloalkalophilic Bacillus sp. I-450. Enzyme Microb. Tech. 2004, 34, 673-681. [CrossRef]

29. Nadell, C.D.; Xavier, J.B.; Levin, S.A.; Foster, K.R. The Evolution of Quorum Sensing in Bacterial Biofilms. PLoS Biol 2008, 6, e14. [CrossRef] [PubMed]

30. Tan, C.H.; Koh, K.S.; Xie, C.; Tay, M.; Zhou, Y.; Williams, R.; Ng, W.J.; Rice, S.; Kjelleberg, S. The role of quorum sensing signalling in EPS production and the assembly of a sludge community into aerobic granules. ISME J. 2014, 8, 1186-1197. [CrossRef] [PubMed]

31. Dobretsov, S.; Teplitski, M.; Paul, V. Mini review: Quorum sensing in the marine environment and its relationship to biofouling. Biofouling 2009, 25, 413-427. [CrossRef] [PubMed] 
32. Miller, M.B.; Bassler, B.L. Quorum sensing in bacteria. Annu. Rev. Microb. 2001, 55, 165-199. [CrossRef] [PubMed]

33. Eberhard, A.; Burlingame, A.L.; Eberhard, C.; Kenyon, G.L.; Nealson, K.H.; Oppenheimer, N.J. Structural identification of autoinducer of Photobacterium fischeri luciferase. Biochemistry 1981, 20, 2444-2449. [CrossRef] [PubMed]

34. Defroidt, T.; Boon, N.; Bossier, P.; Verstraete, W. Disruption of bacterial quorum sensing: An unexplored strategy to fight infections in aquaculture. Aquaculture 2004, 240, 69-88. [CrossRef]

35. Waters, C.M.; Bassler, B.L. Quorum sensing: Cell-to-cell communication in bacteria. Annu. Rev. Cel. Dev. Biol. 2005, 21, 319-346. [CrossRef] [PubMed]

36. Gram, L.; Grossart, H.P.; Schilingloff, A.; Kiroboe, T. Possible Quorum Sensing in Marine Snow Bacteria: Production of Acylated Homoserine Lactones by Roseobacter Strains Isolated from Marine Snow. Appl. Environ. Microb. 2002, 8, 4111-4116. [CrossRef]

37. Frederick, M.R.; Kuttler, C.; Hense, B.; Eberl, H.J. A mathematical model of quorum sensing regulated EPS production in biofilm communities. Theor. Biol. Med. Mod. 2011, 8, 1-29. [CrossRef] [PubMed]

38. Dolfi, S.; Sveronis, A.; Silipo, A.; Rizzo, R.; Cescutti, P. A novel rhamno-mannan exopolysaccharide isolated from biofilms of Burkholderia multivorans C1576. Carbohydr. Res. 2015, 411, 42-48. [CrossRef] [PubMed]

39. Zhang, S.; Santschi, P.H. Application of cross-flow ultrafiltration for isolating exopolymeric substances from a marine diatom (Amphora sp.). Limnol. Oceanogr. Methods 2009, 7, 419-429. [CrossRef]

40. Bergmaier, D.; Lacroix, C.; Macedo, M.G.; Champagne, C.P. New method for exopolysaccharide determination in culture broth using stirred ultrafiltration cells. Appl. Microbiol. Biotechnol. 2001, 57, 401-406. [PubMed]

41. Finore, I.; di Donato, P.; Mastascusa, V.; Nicolaus, B.; Poli, A. Fermentation Technologies for the Optimization of Marine Microbial Exopolysaccharide Production. Mar. Drugs 2014, 12, 3005-3024. [CrossRef] [PubMed]

42. Senni, K.; Pereira, J.; Gueniche, F.; Delbarre-Ladrat, C.; Sinquin, C.; Ratiskol, J.; Godeau, G.; Fischer, A.; Helley, D.; Colliec-Jouault, S. Marine Polysaccharides: A Source of Bioactive Molecules for Cell Therapy and Tissue Engineering. Mar. Drugs 2011, 9, 1664-1681. [CrossRef] [PubMed]

43. Laurienzo, P. Marine Polysaccharides in Pharmaceutical Applications: An Overview. Mar. Drugs 2010, 8, 2435-2465. [CrossRef] [PubMed]

44. Courtois, A.; Berthou, C.; Guezennec, J.; Boisset, C.; Bordron, A. Exopolysaccharides Isolated from Hydrothermal Vent Bacteria Can Modulate the Complement System. PLoS ONE 2014, 9, e94965. [CrossRef] [PubMed]

45. Lelchat, F.; Cozien, J.; Le Costaouec, T.; Brandilly, C.; Schmitt, S.; Baudoux, A.; Colliec-Jouault, S.; Boisset, C. Exopolysaccharide biosynthesis and biodegradation by a marine hydrothermal Alteromonas sp. Strain. Appl. Microb. Biotechnol. 2015, 99, 2637-2647. [CrossRef] [PubMed]

46. Sun, M.; Zhao, F.; Shi, M.; Zhang, X.; Zhou, B.; Zhang, Y.; Chen, X. Characterization and Biotechnological Analysis of a New Exopolysaccharide from the Arctic Marine Bacterium Polaribacter sp. SM1127. Nat. Sci. Rep. 2015, 5, 18435. [CrossRef] [PubMed]

47. Sun, M.; Liu, S.; Qiao, L.; Chen, X.; Pang, X.; Shi, M.; Zhang, X.; Qin, Q.; Zhou, B.; Zhang, Y.; et al. A novel exopolysaccharide from deep-sea bacterium Zunongwangia profunda SM-A87: Low-cost fermentation, moisture retention, and antioxidant activities. Appl. Microbiol. Biot. 2014, 98, 7437-7445. [CrossRef] [PubMed]

48. Priyanka, P.; Arun, A.; Rekha, P. Sulfated exopolysaccharide produced by Labrenzia sp. PRIM-30, characterization and prospective applications. Int. J. Biol. Macromol. 2014, 69, 290-295.

49. Lelchat, F.; Cerantola, S.; Brandily, C.; Colliec-Jouault, S.; Baudoux, A.; Ojima, T.; Boisset, C. The marine bacteria Cobetia marina DSMZ 4741 synthesizes an unexpected K-antigen-like exopolysaccharide. Carbohydr. Polym. 2015, 124, 347-356. [CrossRef] [PubMed]

50. Priyanka, P.; Arun, A.; Young, C.; Rekha, P. Prospecting exopolysaccharides produced by selected bacteria associated with marine organisms for biotechnological applications. Chin. J. Polym. Sci. 2015, 33, $236-244$. [CrossRef]

51. Hongpattarakere, T.; Cherntong, N.; Wichienchot, S.; Kolida, S.; Rastall, R. In vitro prebiotic evaluation of exopolysaccharides produced by marine isolated lactic acid bacteria. Carbohydr. Polym. 2012, 87, 846-852. [CrossRef]

52. Deschatre, M.; Ghillebaert, F.; Guezennec, J.; Simon, C. Sorption of Copper(II) and Silver(I) by Four Bacterial Exopolysaccharides. Appl. Biochem. Biotechnol. 2013, 171, 1313-1327. [CrossRef] [PubMed] 
53. Nogueira, P.; Melão, M.; Lombardi, A.; Nogueira, M.; Vieira, A. The effects of Anabaena spiroides exopolysaccharides on copper accumulation in an aquatic food chain. Aquat. Toxicol. 2009, 93, 125-130. [CrossRef] [PubMed]

54. Raj, R.; Dalei, K.; Chakraborty, J.; Das, S. Extracellular polymeric substances of a marine bacterium mediated synthesis of CdS nanoparticles for removal of cadmium from aqueous solution. J. Coll. Interf. Sci. 2016, 462, 166-175. [CrossRef] [PubMed]

55. Carrión, O.; Delgado, L.; Mercade, E. New emulsifying and cryoprotective exopolysaccharide from Antarctic Pseudomonas sp. ID1. Carbohydr. Polym. 2015, 117, 1028-1034. [CrossRef] [PubMed]

56. Bramachari, P.; Kishor, P.K.; Ramadevi, R.; Kumar, R.; Rama, R.B.; Dubei, K. Isolation and Characterization of Mucous Exopolysaccharide (EPS) Produced by Vibrio furnissii Strain VB0S3. J. Microbiol. Biotechnol. 2007, $17,44-51$.

57. Iyer, A.; Mody, K.; Jha, B. Enzyme and Emulsifying properties of a marine bacterial exopolysaccharide. Microb. Technol. 2006, 38, 220-222. [CrossRef]

58. Liu, S.; Chen, X.; He, H.; Zhang, X.; Xie, B.; Yu, Y.; Chen, B.; Zhou, B.; Zhang, Y. Structure and Ecological Roles of a Novel Exopolysaccharide from the Arctic Sea Ice Bacterium Pseudoalteromonas sp. Strain SM20310. Appl. Env. Microbiol. 2013, 79, 224-230. [CrossRef] [PubMed]

59. David, G.; Davies, M.; Parsek, R.; Pearson, J.P.; Iglewski, B.H.; Costerton, J.W.; Greenberg, E.P. The Involvement of Cell-to-Cell Signals in the Development of a Bacterial Biofilm. Science 1998, 280, $295-298$. [CrossRef]

60. Swift, S.; William, P.; Gsab, S. N-Acylhomoserine lactones and quorum sensing in proteobacteria. In Cell-Cell Signaling in Bacteria; Dunny, G.M., Winans, S.C., Eds.; ASM Press: Washington, D.C., USA, 1999; pp. 291-314.

61. Bassler, B.L. A multichannel two-component signaling relay controls quorum sensing in Vibrio harveyi. In Cell-Cell Signaling in Bacteria; Dunny, G.M., Winans, S.C., Eds.; ASM Press: Washington, DC, USA, 1999; pp. 259-273.

62. Tommonaro, G.; Abbamondi, G.R.; Iodice, C.; Tait, K.; de Rosa, S. Diketopiperazines Produced by the Halophilic Archaeon, Haloterrigena hispanica, Activate AHL Bioreporters. Microb. Ecol. 2012, 63, 490-495. [CrossRef] [PubMed]

63. Abbamondi, G.R.; de Rosa, S.; Iodice, C.; Tommonaro, G. Cyclic Dipeptides Produced by Marine Sponge-Associated Bacteria as Quorum Sensing Signals. Nat. Prod. Commun. 2014, 9, 229-232. [PubMed]

64. Kendall, M.M.; Sperandio, V. What a Dinner Party! Mechanisms and Functions of Interkingdom Signaling in Host-Pathogen Associations. MBio 2016, 7, e01748-15. [CrossRef] [PubMed]

65. Schikora, A.; Schenk, S.T.; Hartmann, A. Beneficial effects of bacteria-plant communication based on quorum sensing molecules of the $N$-acyl homoserine lactone group. Plant Mol. Biol. 2016, 90, 605-612. [CrossRef] [PubMed]

66. Nealson, K.H.; Platt, T.; Hastings, J.W. Cellular control of the synthesis and activity of the bacterial luminescence system. J. Bacteriol. 1970, 104, 313-322. [PubMed]

67. Whiteley, M.; Lee, K.M.; Greenberg, E.P. Identification of genes controlled by quorum sensing in Pseudomonas aeruginosa. PNAS 1999, 96, 13904-13909. [CrossRef] [PubMed]

68. Shukla, S.K.; Mangwani, N.; Rao, T.S.; Das, S. Biofilm-mediated bioremediation of polycyclic aromatic hydrocarbons. In Microbial Biodegradation and Bioremediation, 1st ed.; Das, S., Ed.; Elsevier: London, UK, 2014; pp. 203-232.

69. De Kievit, T.R.; Gillis, R.; Marx, S.; Brown, C.; Iglewski, B.H. Quorum sensing genes in Pseudomonas aeruginosa biofilms: Their role and expression patterns. Appl. Environ. Microb. 2001, 67, 1865-1873. [CrossRef] [PubMed]

70. Huang, Y.; Zeng, Y.; Yu, Z.; Zhang, J.; Feng, H.; Lin, X. In silico and experimental methods revealed highly diverse bacteria with quorum sensing and aromatics biodegradation systems a potential broad application on bioremediation. Bioresour. Technol. 2013, 148, 311-316. [CrossRef] [PubMed]

71. Mangwani, N.; Kumari, S.; Das, S. Involvement of quorum sensing genes in biofilm development and degradation of polycyclic aromatic hydrocarbons by a marine bacterium Pseudomonas aeruginosa N6P6. Appl. Microb. Biotechnol. 2015, 99, 10283-10297. [CrossRef] [PubMed]

72. Lynch, M.J.; Swift, S.; Kirke, D.F.; Keevil, C.W.; Dodd, C.E.R.; Williams, P. The regulation of biofilm development by quorum sensing in Aeromonas hydrophila. Environ. Microbiol. 2002, 4, 18-28. [CrossRef] [PubMed] 
73. Husain, F.M.; Ahmad, I.; Khan, M.S.; Al-Shabib, N.A. Trigonella foenum-graceum (Seed) Extract Interferes with Quorum Sensing Regulated Traits and Biofilm Formation in the Strains of Pseudomonas aeruginosa and Aeromonas hydrophila. Evid. Based Complement. Alternat. Med. 2015. [CrossRef] [PubMed]

74. Norizan, S.N.M.; Yin, W.F.; Chan, K.G. Caffeine as a potential quorum sensing inhibitor. Sensors 2013, 13, 5117-5129. [CrossRef] [PubMed]

75. Fuqua, C.; Greenberg, E.P. Listening in on bacteria: Acyl-homoserine lactone signaling. Nat. Rev. 2002, 3, 685-695. [CrossRef] [PubMed]

76. Krishnan, T.; Yin, W.F.; Chan, K.G. Inhibition of quorum sensing-controlled virulence factor production in Pseudomonas aeruginosa PAO1 by Ayurveda spice clove (Syzgium Aromaticum) bud extract. Sensors 2012, 12, 4016-4030. [CrossRef] [PubMed]

77. Tan, W.S.; Yunos, N.Y.; Tan, P.W.; Mohamad, N.I.; Adrian, T.G.; Yin, W.F.; Chan, K.G. Characterisation of a marine bacterium Vibrio brasiliensis T33 producing $N$-acyl homoserine lactone quorum sensing molecules. Sensors 2014, 14, 12104-12113. [CrossRef] [PubMed]

78. Tan, P.W.; Tan, W.S.; Yunos, N.Y.; Mohamad, N.I.; Adrian, T.G.; Yin, W.F.; Chan, K.G. Short chain N-acyl homoserine lactone production in tropical marine Vibrio sinaloensis strain T47. Sensors 2014, 18, 12958-12967. [CrossRef] [PubMed]

79. Brian-Jaisson, F.; Ortalo-Magné, A.; Guentas-Dombrowsky, L.; Armougom, F.; Blache, Y.; Molmeret, M. Identification of bacterial strains isolated from the Mediterranean Sea exhibiting different abilities of biofilm formation. Microb. Ecol. 2014, 68, 1-17. [CrossRef] [PubMed]

80. Ayé, A.M.; Bonnin-Jusserand, M.; Brian-Jaisson, F.; Ortalo-Magné, A.; Culioli, G.; Nevry, R.K.; Rabah, N.; Blache, Y.; Molmeret, M. Modulation of violacein production and phenotypes associated with biofilm by exogenous quorum sensing $N$-acylhomoserine lactones in the marine bacterium Pseudoalteromonas ulvae TC14. Microbiol. 2015, 161, 2039-2051. [CrossRef]

81. Long, R.A.; Azam, F. Antagonistic interactions among marine pelagic bacteria. Appl. Environ. Microbiol. 2001, 67, 4975-4983. [CrossRef] [PubMed]

82. Kiørboe, T. Colonization of marine snow aggregates by invertebrate zooplankton: Abundance, scaling, and possible role. Limnol. Oceanogr. 2000, 45, 479-484. [CrossRef]

83. Ploug, H.; Grossart, H.P. Bacterial growth and grazing on diatom aggregates: Respiratory carbon turnover as a function of aggregate size and sinking velocity. Limnol. Oceanogr. 2000, 45, 1467-1475. [CrossRef]

84. Schweitzer, B.; Huber, I.; Amann, R.; Ludwig, W.; Simon, M. $\alpha$ - and $\beta$-Proteobacteria control the consumption and release of amino acids in lake snow aggregates. Appl. Environ. Microbiol. 2001, 67, 632-645. [CrossRef] [PubMed]

85. Kjelleberg, S.; Molin, S. Is there a role for quorum sensing signals in bacterial biofilms? Cur. Opin. Microbiol. 2002, 5, 254-258. [CrossRef]

(C) 2016 by the authors; licensee MDPI, Basel, Switzerland. This article is an open access article distributed under the terms and conditions of the Creative Commons Attribution (CC-BY) license (http://creativecommons.org/licenses/by/4.0/). 